history of the sun, the heat of which has been shown by geological evidence to have varied considerably during the last 1,000 million years. Simpson's pluvial theory is dealt with-a theory which assumes that increased precipitation of moisture in the form of rain and snow was due to an increase in the heat of the sun-but no satisfactory explanation has yet been given of the cause of the variation in the sun's heat. Regarding novæ and super-novæ, no explana. tion is suggested beyond the statement that "atomic energy has no doubt something to do with it". Among some of the problems still awaiting solution are the origin of the solar system, the evolution of the stars, the structure and evclution of the universe, and cosmic rays. This lecture provides a very helpful summary of the progress of astronomy in compara. tively recent times and also of the problems still awaiting solution, some of which appear more intractioble now than they did twenty years ago.

Royal Scottish Museum : Natural History Department

WrTH the refopenting of the Beasts of Prey Hall, the main halls of galleries belonging to the Natural History Pfpartment of the Royal Scottish Museum, Edin furgh, are now available to the public. These number twelve in all, allocated as follows: British fauna (2), mammals (3), extinct animals (1), foreign birds (1), amphibians and reptiles (1), fishes and molluses (1), entomology (1), biology (1), and children's gallery (1). In addition, the study room, for use of students of the collections, is now open. During the War, many of the collections were removed, and the opportunity has now been taken to re-arrange much of the material. In addition, two specialist galleries for students are in use. An introductory hall entitled "The Story of the Earth", serving as an introduction to natural history and geology, is in course of preparation. A gallery of maring invertebrates is projected.

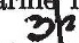

Univertal Decimal Classification

THE first abridgment of the full universal decimal elassification in English has been published by the British Stan do buds' Institution as B.S. 1000 A. : 1948. It confstsp 128 pages and costs $25 s$. It is intended fo th libraries or private collections where dyouled subdivision of subjects is not required, or in special libraries using the full classification in a given subject but requiring an abridged classification for other fields. It is based on the official abridgment in the Dutch language, fifth edition, with the help, mainly in the sciences, of the abridgment published by H.M. Stationery Office, under the title "Classification for Works in Pure and Applied Science in the Science Museum Library", third edition. The abridgment should form a useful introduction and guide to the complete fourth edition in English, which is being published by the British Standards Institption, section by section.

\section{Correction of Magnesium Deficiency in Tomatoes}

MAGNESIUM chlogesis is widespread among tomatoes grown unferasis in Great Britain. It probably cayses a ofnsiderable loss of yield, and economic meshods for its correction are therefore urgently rechired. D. J. D. Nicholas shows (J. Hort. Sci., 24, No. 1,1-18; June 1948) that this can best be accomplished by sprays of two per cent of magnesium sulphate applied to the foliage five times at intervals of two or three weeks. This results in the application of less than 5 cwt. per acre, compared with 10-20 cwt. of calcined kieserite, found necessary for soil applications. Soil factors probably immobilize a large proportion of the soil dressings of magnesium sulphate. Interactions of magnesium with potassium and nitrogen are also discussed in the paper.

\section{Chelsea Polytechnic}

THE fifty-third annual report of Chelsea Polytechnic is intg because of the attractive way in which Hafoms have been presented. Besides the usual information about the number and range of clafs ds and examination successes, the report contains a tetailed analysis of the occupations of evening students, the geographical distribution of students, the kind of research undertaken by advanced students and particulars of services rendered by members of the staff in a voluntary capacity to various kinds of learned and other societies. The examination statistics show that, during the last two years, one D.Sc., five Ph.D.s and seventeen M.Sc.s were obtained, figures of considerable significance for those who wish to see some evidence that the recommendations of the Percy Committee on Higher Technological Education have not been forgotten. This report, so clearly and precisely presented, is a fine example of what such a document can be in building up the corporate spirit of a large institution.

New Zealand Earthquakes during October 1948

NINE strong distant earthquakes were registered during Ogtol 1948 by the New Zealand seismograph s. Stated at Auckland, Arapuni, Christchurch, Kaimat?, New Plymouth, Tuai and Wellington, according to the report from the Dominion Observatory, Wellington. In addition, eighteen earthquakes and tremors were felt by people in New Zealand during the month. The greatest of these had instrumental strength $4 \frac{1}{2}$ and was felt at Dunedin and Monowai on October 9 . The next most intense had instrumental strength $4 \frac{1}{4}$, and these were felt on October 16 at Otaki and Wanganui, and on October 29 at Hanmer Springs.

\section{Editorial Board of Chymia}

The Unilersity of Pennsylvania Press has announced the appointment of Henry M. Leicester, professor of biochemistry, College of Physicians and Surgeons in San Francisco, as editor-in-chief of Chymia : Annual Studies in the History of Chemistry. Dr. Leicester, who succeeds the late Tenney L. Davis as editor, is chairman of the History of Chemistry Division, American Chemical Society, and associate editor of the Journal of Chemical Education. Prof. John Read, professor of chemistry and director of the Chemistry Research Laboratory, University of St. Andrews, is the new associate editor of Chymia. Other members of the editorial board are : Claude $K$. Deischer, Rudolf Hirsch, Herbert S. Klickstein and Eva V. Armstrong.

\section{University of Lohdon: Appointments}

THE following announcements of appointments have recently boen issued: Prof. H. C. Darby has accepted an invjation to the University chair of geography tenable at University College, and Mr. W. O. Lester Snath to the University chair of sociology of education tenable at the Institute of Education, both as from October 1, 1949. Dr. P. E. Vernon has been appointed to the University chair of educational psychology tenable at the Institute of Education, as 
from October 1, 1949. Appointments to readerships: Dr. E. T. Eady to the University readership in physical climatology tenable at the Imperial College of Science and Technology, as from October 1, 1949 ; Dr. A. J. Marshall to the University readership in zoology and comparative anatomy tenable at St. Bartholomew's Hospital Medical College, as from Oetober 1, 1949 ; Mr. N. H. Martin to the University readership in chemical pathology tenable at St. George's Hospital Medical School, as from April 1, 1949 ; Dr. J. R. Raeburn to the University readership in agricultural economics tenable at the London School of Economics, as from October 1, 1949; Dr. J. W. Smith to the University readership in chemistry tenable at Bedford College, as from October 1, 1949.

\section{University of Bristol: Appointments}

DR. H. S. HeLLER, reader and head of the Depart. ment of Pharmacology and Practical Pharmacy in the J/iversity of Bristol, has been appointed the finst occupant of the new chair of pharmacology in the University. Dr. H. A. Heilbronn, reader in pure mathematics in the University, has been appointed to succeed Prof. H. R. Hassé as Henry Overton Wills professor of mathematics. Both these appointments take effect in the session 1949-50.

\section{Announcements}

THE Stamp Memorial Lecture will be given at the Senaty Aouse, University of London, by Prof. A. C. Pigou, emeritus professor of political economy, University of Cambridge, on May 13 at 5.30 p.m.; he will speak on "Wage Statistics and Wage Policy", Admission is free, without ticket.

THE Silvanus Thompson Memorial Lecture for 1949 of the British Institute of Radiology will be delixered by Dr. F. G. Spear, of the Strangeways Research Laboratory, Cambridge, at the Institute on April 28; he will speak on "The National Radium Commission in Retrospect".

THE thirty-seventh Wilbur Wright Memorial Lecture of the Royal Aeronautical Society will be given by Dr. Hugh Dryden, director of aeronautical research to the National Advisory Committee for Aeronautics, at the Royal Institution, London, on April 28 at 6 p.m. ; Dr. Dryden will speak on "The Aeronautical Research Scene-Goals, Methods and Accomplishments".

IN connexion with the series of lectures on the "Development of Taxonomy" given at the rooms of the Linnegn Society during the past winter, there will be a demonstration at the Herbarium, Royal Botanic Gardens, Kew, on May 7 at $2.30-5$ p.m. The demonstration, which has been arranged by the Linnean Society and Systematics Association, will illustrate the history and methods of botanical taxonomy from 1753 to the present day, and is primarily intended for advanced university students and teachers.

DR. T. W. PARKER has recently been appointed deputy director of building research in the Depart. ment of Scientific and Industrial Research. Dr. Parker who was educated at the University of Durham joined the staff of the Building Research Station in 1930. His research work has been mainly concerned with building materials and their use in structures. For some years he was also responsible for the Station's programme of work at the Fire Testing Station, Elstree, before this was taken over by the Fire Research Organisation of the Department.
THE Challenger Society is prepared to consider applications for small grants in aid of research in marine blology or oceanography at a recognized laboratory during the year June 1949-June 1950. Applications, accompanied by details of the proposed research, should reach the honorary secretary, Mr. N. B. Marshall, British Museum (Natural History), London, S.W.7, before the end of May.

AN award is to be made of the studentship in experimental and mathematical aeronautics research established in memory of Edward Teshmaker Busk, who in 1914 lost his life while flying an experimental aeroplane. The studentship, which is worth $£ 165$ and tenable for one year at the University of Cambridge, is open to any British man or woman less than twenty. five years of age. Full details may be obtained from the Professor of Aeronautical Engineering, Engineer. ing Laboratory, Cambridge.

THE Medical Research Council is offering the follow. ing travelling fellowships for the academic year 194950: Rockefeller medical fellowships for postgraduates resident in Great Britain to work in the United States or elsewhere; Dorothy Temple Cross research fellowships in tuberculosis for British subjects to work elsewhere than in Great Britain. Both fellow. ships are worth $£ 650$ per year and there are travelling allowances and a $£ 250$ marriage allowance. Applica. tion forms, to be completed by June 1, may be obtained from the Secretary, Medical Research Council, 38 old Queen Street, Westminster, London, S.W.1.

AN exhibition of calculating machines and equip. ment will be held in the Firth Hall, University of Sheffield, dyring April 29 (2.30-8.0 p.m.) and April 30 (10.0 a.n.-6.0 p.m.). The exhibition will be opened by Prof. D. R. Hartree, Plummer professor of mathematical physics, University of Cambridge, who will speak on "Some Recent Developments in Calculating Machines". Lectures will also be given by Mr. G. B. Hey (Trustee Department, District Bank, Ltd.) on "Applications of Punched Card Machines in Accounting and Scientific Computing", and Dr. E. T. Goodwin (Mathematics Division, National Physical Laboratory) on "Calculating Machines : their Nature and Applications". Admission is free.

THE Coal Tar Research Association, now incor. porated under the Companies Act of 1948, has leased premises at Gomersal, near Leeds, for its research station. It is expected that the headquarters of the Association will move from the present address, 9 Harley Street, London, W.1, in June and that the laboratories will be completed later in the year.

THE National Physical Laboratory at Teddington is holding an 'open day' on May 26 from 2.30-6.0 p.m., to which representatives of industrial organisations are being invited. This is an opportunity for members of industry to see the wide range of scientific research and investigational work undertaken at the Labora. tory, and a number of tickets is being reserved for postal applications. Accredited representatives of industrial organisations who would like to visit the Laboratory and who are not already in contact with its work are invited to apply to the Director, National Physical Laboratory, Teddington, Middlesex, not later than May 14.

ERratum.-In the communication entitled "Shape Factor in Particle-Size Measurement" in Nature of April 2 , p. 527, line 5 from end, for " $K$ is then tho standard deviation" read " $K_{2}$ is then the standard deviation ..." 